Tersedia Online di http://journal2.um.ac.id/index.php/wsd/

ISSN 0854-8293 (cetak) ISSN 2622-5883 (online)

\title{
PENINGKATAN HASIL BELAJAR MENGIDENTIFIKASI KERAGAMAN SOSIAL, EKONOMI, BUDAYA, ETNIS, DAN AGAMA DI PROVINSI SETEMPAT MELALUI MODEL CROSSWORD PUZZLE KELAS IV SEKOLAH DASAR
}

\author{
Mira Iswanti, Suminah' Sutansi \\ PP3 Jl. Ir. Soekarno No.1 Blitar, Universitas Negeri Malang \\ e-mail:mira.iswanti6@gmail.com
}

\begin{abstract}
Abstrak Peneliti ini bertujuan untuk mendeskripsikan pengaruh model crossword puzzle pada materi mengidentifikiasi keragaman sosial, ekonomi, budaya, etnis, dan agama di provinsi setempat kelas IV. Penelitian ini dilakukan dalam II siklus dengan II pertemuan pada setiap siklus. Setiap siklus terdiri dari 4 tahap yakni perencanaan, pelaksanaan, pengamatan, dan refleksi. Penerapan model ini dapat meningkatkan aktivitas guru dan siswa serta dapat meningkatkan hasil belajar.
\end{abstract}

Kata kunci: keragaman, hasil belajar, crossword puzzle

Kurikulum 2013 merupakan kurikulum berbasis karakter. Kurikulum 2013 merupakan kurikulum yang mengedepankan tiga aspek yaitu sikap, pengetahuan, dan keterampilan. Salah satu Kompetensi Dasar muatan IPS kelas IV dalam kurikulum 2013 yakni, "Mengidentifikasi keragaman sosial, ekonomi, budaya, etnis, dan agama di provinsi setempat sebagai identitas bangsa Indonesia; serta hubungannya dengan karakteristik ruang" (Depdiknas, 2006:1). Pembelajaran IPS diintegrasikan melalui beberapa konsep diantaranya ruang, koneksi antar ruang, dan waktu.

Berdasarkan pembelajaran IPS yang telah dilakukan guru menunjukkan hasil pembelajaran IPS di kelas IV sangat rendah dari 12 siswa di kelas IV hanya 4 siswa atau 33 $\%$ yang mendapat nilai diatas atau sama dengan 70 yang merupakan Kriteria Ketuntasan Minimal (KKM) di SDN Kandangan 02.

Berdasarkan hasil wawancara yang dilakukan pada siswa kelas IV SDN Kandangan 02 Kabupaten Blitar, diperoleh hasil bahwa wawasan IPS materi keragaman suku di Jawa
Timur sangat rendah. Pemahaman siswa terhadap karateristik dan penyebaran suku di Jawa Timur sangat rendah. Siswa hanya mengetahui karakteristik suku Jawa saja. Padahal, selain suku Jawa terdapat suku-suku lainnya yang mempunyai keragaman dan karakteristik tersendiri. Maka dari hal tersebut pemahaman siswa terhadap materi keragaman sosial, ekonomi, budaya, etnis dan agama di provinsi Jawa Timur kurang.

Dalam mengatasi kesenjangan permasalahan telah dilakukan perbaikan proses pembelajaran yang dapat menumbuhkan motivasi, aktivitas belajar, dan sikap ilmiah pada diri siswa sehingga dapat meningkatkan hasil belajar siswa. Perbaikan proses pembelajaran dapat dilakukan dengan menggunakan crossword puzzle sesuai dengan pendapat Zaini,dkk(2008:71).

\section{METODE}

Penelitian ini menggunakan pendekatan penelitian kualitatif dan jenis penelitian adalah Penelitian Tindakan Kelas (PTK). 
Model penelitian ini dari Kemmis dan Mc Taggart. Secara garis besar terdiri dari 4 tahapan menurut Arikunto (2009:16) yaitu: (1) penyusunan rencana, (2) tindakan, (3) observasi, dan (4) refleksi.

Sumber data penelitian ini adalah guru dan siswa kelas IV SDN Kandangan 02. Data dalam penelitian ini adalah proses dan hasil. Data proses berupa aktivitas guru dan siswa. Sedangkan data hasil berupa penilaian sikap, pengetahuan, dan keterampilan.

Teknik pengumpulam data yang digunakan yaitu observasi, tes, dokumentasi, dan catatan lapangan. Data yang diperoleh dari penelitian ini dianalisis secara kualitatif. Data yang terhimpun dianalisis dengan prosedur (1) reduksi, (2) penyajian data, dan (3) penarikan kesimpulan.

\section{HASIL}

Pada pratindakan diperoleh hasil belajar siswa dengan rata-rata 50,12 dan dengan persentase ketuntasan 33,3\% dengan predikat sangat kurang. Siklus I pertemuan I persentase aktivitas guru yaitu $100 \%$ dan aktivitas siswa $72,2 \%$. Rata-rata nilai pengetahuan 70,6 dengan ketuntasan 50\% dengan kriteria kurang sekali. Pada pertemuan I, guru belum bisa menstimulus siswa untuk bertanya dan mengajukan pendapat dan mengondisikan kelas serta siswa belum bisa dikondisikan dan kerja sama antar kelompok masih kurang.

Pada siklus II pertemuan II mengalami peningkatan. Persentase aktivitas guru 100\% sedangkan aktivitas siswa 88,8\%. Rata-rata nilai pengetahuan yaitu 74 dengan ketuntasan klasikal 50\%. Pada pertemuan ini, guru terburu-buru dalam menyampaikan materi dan perlu penambahan media. Siswa sudah bisa dikodisikan meskipun ada 4 siswa yang masih berbicara sendiri serta kerja sama antar kelompok sudah mulai muncul.

Siklus II pertemuan II berjalan dengan cukup baik. Persentase aktivitas guru 100\% dan aktivitas siswa 94,4\%. Rata-rata hasil belajar siswa meningkat menjadi 79,75 dengan ketuntasan klasikal 75\%. Pada pertemuan ini, siswa terlibat aktif dalam penggunaan media, antusiasme siswa meningkat namun peran ketua kelompok belum muncul serta guru sudah bisa mengondisikan kelas.

Siklus II pertemuan II berjalan lebih baik dari pertemuan I. Persentase aktivitas guru dan siswa $100 \%$ dan nilai rata-rata hasil belajar 83,125 dengan ketuntasan klasikal 83,3\%. Temuan penelitian pada pertemuan ini keaktifan siswa dalam menjawab pertanyaan sudah baik, dibuktikan dengan banyaknya siswa yang menyampaikan pendapat, interaksi siswa ketika bekerja dalam kelompok sudah baik, guru juga sudah bisa mengelola kelas tetap kondusif selama pembelajaran berlangsung dan juga dapat mengendalikan siswa untuk tetap tertib pada saat pembelajaran, antusiasme siswa dalam belajar meningkat, siswa sudah bisa mengidentifikasi keragaman sosial, ekonomi, budaya, etnis, dan agama suku, dan guru harus bisa memfasilitasi keaktifan siswa.

\section{PEMBAHASAN}

Guru sudah melakukan persiapan sebelum pembelajaran dimulai. Materi siklus I pertemuan I adalah mengidentifikasi keragaman sosial, ekonomi, sosial, budaya, etnis, dan agama suku Jawa di Jawa Timur. Guru sudah menerapkan langkah-langkah namun belum maksimal. Guru belum bisa menstimulus siswa untuk bertanya dan mengajukan pendapat. Hal tersebut belum sesuai dengan Djumarah (2006:185) bahwa guru perlu menerapkan prinsip keluwesan yang dapat mencegah adanya kemungkinan seperti keributan, tidak ada perhatian, tidak mengerjakan tugas, dsb. Siswa juga belum mempunyai semangat dalam belajar, kurang bisa bekerja sama karena guru belum bisa mengelola kelas dengan baik. Guru hendaknya menerapkan prinsip pengelolaan kelas yaitu penekanan hal-hal positif. Hal tersebut sejalan dengan pendapat menurut Djumarah (2006:185) bahwa guru juga perlu menekankan pada hal-hal positif dengan memberikan penguatan serta memperingati siswa yang bertingkah laku negatif. 
Siklus I pertemuan II dengana materi mengidentifikasi keragaman sosial, ekonomi, sosial, budaya, etnis, dan agama suku Tengger di Jawa Timur. Guru sudah melakukan sintaks pembelajaran dengan sangat baik. Namun, masih ada siswa yang berbicara sendiri dan perlu ada penambahan media pembelajaran yang menarik. Guru hendaknya menambah media pembelajaran untuk menarik perhatian siswa. Hal tersebut sesuai dengan pendapat Sadiman (2014:7) bahwa media adalah segala sesuatu yang dapat digunakan untuk menyalurkan pesan dari pengirim dan penerima sehingga dapat merangsang pikiran, perasaan, minat, dan perhatian siswa sedimikian rupa sehingga proses belajar terjadi.

Siklus II dilaksanakan berdasarkan refleksi dari tindakan siklus I. Materi pada siklus II pertemuan II yaitu mengidentifikasi keragaman sosial, ekonomi, sosial, budaya, etnis, dan agama suku Madura di Jawa Timur. Guru bisa mengondisikan siswa serta menggunakan media yaitu peta dan video yang melibatkan dengan siswa. Namun, ada beberapa siswa yang pasif dalam pembelajaran karena guru belum menggunakan variasi dalam pembelajaran. Hendaknya guru memaksimalkan keterampilan memberi perhatian. Hal tersebut sejalan dengan pendapat Djumarah, (2006:186) bahwa keterampilan memberi perhatian terdiri atas visual dan verbal untuk penciptaan dan pemeliharaan kondisi belajar.

Siklus II pertemuan II dengan materi mengidentifikasi keragaman sosial, ekonomi, sosial, budaya, etnis, dan agama suku Osing di Jawa Timur. Guru sudah mampu mengelola kelas dengan baik, menumbuhkan semangat siswa dalam pembelajaran, siswa mampu bekerja sama dan mempunyai semangat bersaing dalam mengerjakan teka-teki. Hal ini terbukti karena guru dan siswa sudah melaksanakan pembelajaran sesuai dengan langkah-langkahnya menurut Siberman (2014:256) sebagai berikut: (1) menjelaskan istilah penting terkait dengan mata pelajaran yang diajarkan, (2) menyusun teka-teki dengan memuat unsur-unsur materi, (3) menyusun kata-kata pemandu tekateki silang, 4) membagikan kepada siswa secara individu atau kelompok, (5) menyampaikan peraturan, (6) menentukan batas waktu, dan (7) memberikan reward.

Penerapan model crossword puzzle tersebut sudah berbasis menyenangkan. Hal tersebut sejalan menurut Zaini dkk (2008:71) menyatakan bahwa teka-teki dapat digunakan sebagai pembelajaran yang baik dan menyenangkan tanpa kehilangan esensi belajar yang sedang berlangsung, bahkan pembelajaran dengan ini dapat melibatkan pastisipasi siswa secara aktif sejak awal.

Berdasarkan data yang diperoleh, terlihat aktivitas guru dan aktivitas siswa pada siklus I belummaksimaldanpadasiklusIIpembelajaran sudah sesuai dengan yang diharapkan. Hal ini didukung dengan hasil observasi aktivitas guru dan siswa dengan menerapkan model crossword puzzle. Aktivitas guru pada siklus I mencapai $100 \%$ dengan predikat sangat baik dan pada siklus II stabil dengan persentase $100 \%$ dengan predikat sangat baik. Sementara itu aktivitas siswa pada siklus I mencapai $80,5 \%$ dengan predikat baik, pada siklus II mengalami peningkatan yang signifikan yaitu mencapai 97,2\% dengan predikat sangat baik. Peningkatan tersebut membuktikan bahwa dengan menerapkan model crossword puzzle dapat meningkatkan aktivitas guru dan siswa dalam proses pembelajaran muatan IPS materi materi mengidentifikasi keragaman sosial, ekonomi, sosial, budaya, etnis, dan agama suku di Jawa Timur pada siswa kelas IV SDN Kandangan 02 Kabupaten Blitar.

Pembelajaran melalui model crossword diupayakan untuk meningkatkan hasil belajar materi mengidentifikasi keragaman sosial, ekonomi, budaya, etnis, dan agama di provinsi setempat di kelas IV SDN Kandangan 02 Kabupaten Blitar. Hamalik menjelaskan (2005:30) hasil belajar akan tampak pada aspek-aspek tingkah laku pelajar yaitu, pengetahuan, pengertian kebiasaan, keterampilan, apresiasi, emosional, hubungan sosial, jasmani, etis atau budi pekerti, dan sikap. 
Hal tersebut senada dengan Susanto (2016:5) "hasil belajar siswa adalah kemampuan yang diperoleh anak setelah melalui kegiatan pembelajaran. Karena belajar itu sendiri merupakan suatu bentuk perubahan yang relatif menetap".

Berdasarkan pernyataan diatas dapat disimpulkan bahwa hasil belajar adalah perubahan yang diperoleh siswa dalam aspek pengethuan, sikap, dan keterampilan setelah melalui kegiatan pembelajaran. Peningkatan hasil belajar siswa diketahui dengan membandingkan hasil rekapitulasi nilai rata-rata hasil belajar siswa pada tahap pratindakan dan sesudah diberi tindakan yaitu siklus I dan II.

Pada tahap pratindakan nilai rata-rata pratindakan hanya 50,12 dengan persentase ketuntasan belajar klasikal hanya 33,3\%. Siswa dikatakan tuntas jika siswa mencapai nilai $\geq 70$. Dari 12 siswa, sebanyak 4 siswa atau $33,3 \%$ siswa telah tuntas belajar, sedangkan 8 siswa atau $66,6 \%$ siswa belum tuntas. Data tersebut menunjukkan bahwa ketuntasan belajar siswa belum mencapai kriteria ketuntasan klasikal yaitu ditentukan yaitu $75 \%$. Rendahnya nilai yang diperoleh siswa pada pratindakan disebabkan dari siswa yang cenderung pasif dan kurang tertarik dan terlibat secara langsung dalam kegiatan pembelajaran. Hal itu dikarenakan guru belum melaksanakan pembelajaran sesuai dengan langkahlangkah di RPP dan masih menggunakan metode konvensional serta satu arah.

Berdasarkan hasil mengidentifikasi keragaman sosial, ekonomi, sosial, budaya, etnis, dan agama suku di provinsi setempat, hasil belajar siswa mengalami peningkatan. Peningkatan nilai rata-rata pada siklus I dan siklus II membuktikan bahwa terjadi perubahan dalam aspek pengetahuan, sikap, dan keterampilan selama pembelajaran. Peningkatan aspek pengetahuan dapat dilihat dari hasil evaluasi, peningkatan aspek sikap yang berupa percaya diri, teliti, dan tanggung jawab, dan peningkatan aspek keterampilan yang berupa membuat laporan identifikasi mengidentifikasi keragaman sosial, ekonomi, sosial, budaya, etnis, dan agama suku di provinsi setempat dapat dilihat pada nilai keterampilan.

Pada siklus I pertemuan I sebanyak 3 siswa menunjukkan sikap percaya diri dan meningkat menjadi 5. Pertemuan I sebanyak 3 siswa menunjukkan sikap teliti, dan meningkat menjadi 4 siswa. Sikap yang terakhir yaitu sikap tanggung jawab pada pertemuan I sebanyak 3 siswa dan meningkat menjadi 6. Sementara untuk nilai keterampilan siswa pada pertemuan I sebesar 50 dengan predikat kurang meningkat menjadi 60,41 dengan predikat cukup pada pertemuan II. Sedangkan nilai pengetahuan pada pertemuan I sebesar 70,6 dengan predikat cukup meningkat menjadi 74 dengan predikat cukup pada pertemuan II.

Berdasarkan kedua pertemuan pada siklus I diperoleh rata-rata nilai akhir hasil belajar siswa sebesar 50 dengan persentase ketuntasan belajar klasikal sebesar 50\% dengan predikat kurang sekali, sedangkan $50 \%$ siswa belum tuntas sehingga belum mencapai kriteria ketuntasan belajar klasikal. Data tersebut menunjukkan bahwa hasil belajar siswa pada siklus I dengan predikat kurang sekali akan tetapi telah mengalami peningkatan dari hasil belajar pada saat pratindakan yang hanya memperoleh nilai rata-rata 61 dengan dengan persentase ketuntasan belajar klasikal sebesar 50,12\%. Oleh karena itu pembelajaran dilanjutkan ke siklus II.

Pada siklus II pertemuan I sebanyak 7 siswa menunjukkan sikap percaya diri dan meningkat menjadi 8. Pertemuan I sebanyak 7 siswa menunjukkan sikap teliti, dan meningkat menjadi 10 siswa. Sikap yang terakhir yaitu sikap tanggung jawab pada pertemuan I sebanyak 9 siswa dan meningkat menjadi 12. Sementara untuk nilai keterampilan siswa pada pertemuan I sebesar 79,16 dengan predikat baik meningkat menjadi 84,38 dengan predikat baik pada pertemuan II. Sedangkan nilai pengetahuan siswa pada pertemuan I 79,75 dengan predikat cukup meningkat menjadi 83,12 dengan predikat baik pada pertemuan II. 
Berdasarkan hasil belajar pada siklus II pertemuan I siswa mendapat nilai rata-rata 79,75 dan terdapat 3 siswa atau $75 \%$ telah tuntas dan untuk pertemuan II siswa mendapat nilai rata-rata 83,12 dengan ketuntasan belajar klasikal $83 \%$. Siklus II diperoleh rata-rata nilai akhir hasil belajar siswa sebesar 81,44 dengan persentase ketuntasan belajar klasikal sebesar 83,3\% dengan predikat baik. Data tersebut menunjukkan bahwa hasil belajar siswa pada siklus II termasuk ke dalam kriteria baik. Hal ini dapat dinyatakan bahwa siklus II meningkat dari siklus I dan pratindakan, ketuntasan belajar siswa juga sudah melebihi ketuntasan belajar klasikal yang ditentukan.

Berdasarkan paparan tersebut dapat disimpulkan bahwa hasil belajar siswa berupa aspek penegetahuan, sikap, dan keterampilan meningkat. Hal tersebut sesuai dengan pendapat Sudjana (2009:3) bahwa hasil belajar pada hakikatmya adalah perubahan tingkah laku yang mencakup bidang kognitif, afektif, dan psikomotor. Dengan demikian dapat dikatakan bahwa penggunaan model crossword puzzle dapat meningkatkan hasil mengidentifikasi keragaman sosial, ekonomi, budaya, etnis dan agama suku di provinsi setempat di kelas IV SDN Kandangan 02 Kabupaten Blitar. Peningkatan hasil belajar siswa pada penelitian ini sejalan dengan penelitian terdahulu yang dilakukan oleh Yuliana (2016) yang berjudul "Peningkatan Hasil Belajar IPS Melalui Pembelajaran Aktif Crossword Puzzle Kelas IV SD Sekarsuli."

\section{SIMPULAN DAN SARAN}

Penerapan model crossword puzzle materi mengidentifikasi keragaman sosial, ekonomi, budaya, etnis, dan agama di provinsi setempat sudah dilakukan dengan baik, berjalan dengan lancar, dan sesuai dengan langkah-langkah di RPP dengan persentase $100 \%$ setiap pertemuan dalam siklus I dan II. Siswa dan guru telah melaksanakan pembelajaran dengan antusiasme dan menyenangkan. Aktivitas siswa dalam setiap pertemuan meningkat dengan siklus I pertemuan I sebesar $72,2 \%$ dan meningkat pada pertemuan II yaitu $88,8 \%$ sedangkan pada siklus II pertemuan I sebesar $94,4 \%$ dan meningkat pada pertemuan II yaitu $100 \%$.

Model crossword puzzle materi mengidentifikasi keragaman sosial, ekonomi, budaya, etnis, dan agama di provinsi setempat dapat meningkatkan hasil belajar siswa. Hasil belajar terdiri dari ranah pengetahuan, sikap, dan keterampilan. Peningkatan terbukti pada saat pratindakan rata-rata nilai siswa yang diperoleh hanya mencapai 50,12 dengan ketuntasan belajar 33,3\%, meningkat menjadi 72,375 dengan ketuntasan belajar 50\% pada siklus I, dan pada siklus II meningkat lagi menjadi 81,44 dengan ketuntasan belajar 83,3\%. Pada aspek keterampilan siklus I dengan rata-rata 55,205 dan 81,77 pada pertemuan II. Aspek sikap yang terdiri atas percaya diri, teliti, dan tanggung jawab dalam setiap pertemuan dalam siklus I dan II meningkat.

Berdasarkan hasil temuan selama pelaksanaan penelitian saran yang dapat diajukan dalam pembelajaran diperlukan persiapan yang baik sebelum menerapkan model Crossword Puzzle ataupun model inovatif yang lain dan penggunaan media pembelajaran yang sesuai materi pembelajaran sehingga dalam pelaksanaan pembelajaran dapat meningkatkan aktivitas baik guru maupun siswa.

\section{DAFTAR RUJUKAN}

Arikunto, S., 2009. Prosedur Penelitian Suatu Pendekatan Praktik. Edisi Revisi 6. Jakarta : Rineka Cipta.

Depdiknas, 2006. Kurikulum Tingkat Satuan Pendidikan. Jakarta : Depdiknas.

Djamarah, S.B. 2006. Strategi Belajar Mengajar. Jakarta : Rineka Cipta.

Kunandar.2011. Penelitian Tindakan Kelas. Jakarta: Rajawali Pers

Hamalik, Oemar. 2005. Kurikulum dan Pembelajaran. Jakarta : Bumi Aksara.

Sadiman, A.S. 2014. Media Pendidikan. Jakarta : PT Raja Grafindo Persada. 
Siberman. 2014. Active Learning; 101 Cara Belajar Siswa Aktif. Bandung: Nuansa. Cendekia.

Sudjana, N. 2009. Penilaian Hasil Proses Belajar Mengajar. Bandung : PT Remaja Rosdakarya.

Susanto, A. 2013. Teori Belajar dan Pembelajaran di Sekolah Dasar. Jakarta : Prenamedia Group.

Yuliana. 2016. Peningkatan Hasil Belajar IPS Melalui Pembelajaran Aktif Crossword Puzzle Kelas IV SD Sekarsuli. Skripsi tidak diterbitkan. FIP : UNY.

Zaini, dkk. 2008. Strategi Pembelajaran Aktif. Yogyakarta : Pustaka Insan Madani. 